\title{
“0 CARNAVAL AQUI EM LAZARIM SEMPRE FOI MEIO MAROTO" MÁSCARAS, TESTAMENTOS E PRÁTICAS CARNAVALESCAS
}

Dulce Simões (Universidade Nova de Lisboa)

Neste artigo questionamos os mecanismos de construção e preservação das práticas carnavalescas, numa comunidade rural cujo componente agrícola se desvaneceu, com o enfoque na cultura popular (BAKHTIN, 2002) e nas práticas performativas (CONNERTON, 1999). Em permanente dialética envolvendo passado e presente, mediada pela memória de nossos informantes, estruturamos o texto em três partes, analisando as mudanças no mundo rural e os sentidos e significados atribuídos à festa, no processo de construção de identidades locais.

CARNAVAL EM PORTUGAL, MÁSCARAS DE LAZARIM, TESTAMENTOS DE COMPADRESE COMADRES, RITUAIS CARNAVALESCOS, REINVENÇÃO DA TRADIÇÃO.

SIMÕES, Dulce. "O carnaval aqui em Lazarim sempre foi meio maroto": máscaras, testamentos e práticas carnavalescas. Textos escolhidos de cultura e arte populares, Rio de Janeiro, v.9, n.1, p. 99-120, mai. 2012. 


\section{"CARNIVAL HERE IN LAZARIM HAS ALWAYS BEEN KIND OF NAUGHTY" \\ MASKS, WILLS AND CARNIVAL PRACTICES}

Dulce Simões (Universidade Nova de Lisboa)

In this article we question the mechanisms of construction and preservation of carnival practices in a rural community in which the agricultural component has faded, focusing on popular culture (BAKHTIN, 2002) and performative practices (CONNERTON, 1999). In constant dialectics between past and present, mediated by the memory of our sources, the text has been structured into three parts, analyzing the changes in rural areas and the senses and meanings attributed to the party in the construction of local identities.

CARNIVAL IN PORTUGAL, MASKS FROM LAZARIM, REINVENTION OF TRADITION, GODFATHERS AND GODMOTHERS WILLS, CARNIVAL RITUALS.

SIMÕES, Dulce. "O carnaval aqui em Lazarim sempre foi meio maroto": máscaras, testamentos e práticas carnavalescas. Textos escolhidos de cultura e arte populares, Rio de Janeiro, v.9, n.1, p. 99-120, mai. 2012. 


\section{INTRODUÇÃO}

As comunidades rurais possuem um conjunto de saberes e de práticas que pretendem preservar e transmitir às gerações futuras, como patrimônio cultural e identitário. A vila de Lazarim, no concelho de Lamego, norte de Portugal, encontrou no carnaval um tempo de exceção para afirmar sua identidade cultural, recuperando os ritos, os símbolos e os textos associados às festas de Inverno. A partir de 1985 as práticas carnavalescas foram institucionalizadas, num modelo performativo que procura mostrar a tradição local ao mundo global. A intervenção da Junta de Freguesia, da Casa do Povo e a vontade política de seus elementos foram determinantes para a reinvenção da tradição, numa ação concertada com a escola e o envolvimento das famílias. No processo de invenção da tradição (HOBSBAWM; RANGER, 1983) recuperamse os saberes de um passado rural que atribui sentido e significado à vida da comunidade, resgatando práticas culturais como capital simbólico (BOURDIEU, 2001).

Na perspectiva etnográfica de uma descrição densa (GEERTZ, 1978), partimos para Lazarim levando na bagagem algumas leituras sobre práticas carnavalescas no norte de Portugal, e os textos divulgados na Internet pela Câmara Municipal de Lamego. Em termos metodológicos, entrelaçamos a história e a antropologia, articulando a pesquisa documental e bibliográfica com o trabalho de campo, ao longo do qual realizamos entrevistas com informantes institucionais (presidente da Junta de Freguesia, presidente da Casa do Povo, pároco local e professor), com informantes privilegiados (artesãos de máscaras e representantes dos grupos dos compadres e das comadres), e conversas informais com residentes e visitantes.

\section{O ESPAÇO, OS LUGARES E AS PESSOAS}

Lazarim é freguesia portuguesa do concelho de Lamego, distrito de Viseu, Beira Alta, com $15,71 \mathrm{~km}^{2}$ de área e população residente de 686 pessoas, distribuídas em 236 famílias segundo os Censos de 2001. Historicamente é identificada através de vestígios arqueológicos pré-celtas, romanos e visigóticos, atribuindo os habitantes sua origem à aldeia das Antas, atualmente desabitada. Os primeiros documentos referentes a Lazarim datam do início do século XIII, quando se intitulava vila, com administração autárquica e o nome associado ao antropônimo latino de um senhor agrário. A estrutura social da comunidade assentava-se na família e no município, implementados pelo sistema de propriedade. A terra era explorada no nível familiar durante três gerações, gozando os herdeiros de preferência na renovação do contrato de 
arrendamento com os senhores da terra, fidalgos e ordens eclesiásticas. A posse da terra determinava a estrutura linhageira e o casamento endogâmico, fixando a herança na linha agnática. A Igreja impunha o casamento exogâmico, tornando nulo o casamento entre parentes, sendo os documentos registrados como divórcios relativos a anulações, por denúncias feitas à Igreja. Em 1273 a povoação ficou praticamente desabitada, em virtude da peste que assolou a Beira, perdendo o título de vila com a promessa de lhe ser restituído após povoamento, e durante 200 anos cessaram referências documentais. Em 1505 recuperou o título de concelho, por contrapartida do reconhecimento público ao novo donatário, "d. João de Menezes, conde e senhor das ditas terras e concelhos" (COSTA, 1977, p. 91). No século XIX voltou a perder o título, recuperando-o simbolicamente em 21 de junho de 1995.

As diferenças entre lugares não são identificáveis no plano material, através da observação do espaço geográfico, porque ele se apresentava homogêneo a nosso olhar. A heterogeneidade justifica-se no nível simbólico e histórico, associada às famílias que os construíram ao longo do tempo, designando-os por Padrão, Vila e Valverde.

Existe uma competição entre os três lugares, e no carnaval sente-se isso, esconde-se para ser melhor, e por um lado até é bom essa competitividade, mas às vezes também é exagerado porque se pode perder o controle da própria pessoa, e criam-se as rivalidades que prejudicam a paz e a serenidade entre as pessoas (Agostinho Ramalho, pároco local). ${ }^{1}$

O lugar do Padrão demarca-se na entrada da vila, circunscrito à zona da ribeira, integrando à direita o solar dos Vazes, deixado por herança para residência oficial do pároco local, e à esquerda o solar do barão de Lazarim em ruínas. O lugar da Vila é o núcleo habitacional mais antigo, com a Casa da Câmara construída em granito, ruas estreitas, em que se misturam as habitações de alvenaria com as de granito e xisto. Valverde fica na encosta e é o núcleo mais moderno, destacado pelas residências em alvenaria. O espaço do Lazarim integra esses lugares, transformados ao longo de gerações por seus habitantes, com os saberes que reproduzem o quotidiano. A terra outrora fértil já não serve para as necessidades econômicas das famílias, apesar de ser mantido o cultivo para o consumo das casas. Os canastros, ao longo dos campos, testemunham um passado ligado à terra, mas presentemente os residentes dependem dos serviços em Lamego ou do trabalho na construção civil, mantendo as atividades agrícolas em paralelo. A maioria das pessoas de Lazarim migrou para Lisboa e o Porto, apesar de se ter verificado emigração bastante significativa para o 
Brasil nas décadas de 1940 e 1950. No Brasil fixaram-se no bairro do Caju, na cidade do Rio de Janeiro, e em São Paulo, e poucos regressaram. Em Lisboa e no Porto criaram comunidades de migrantes, regressando a Lazarim para as festas de Verão, para a matança do porco ou para ajudar nas vindimas. Durante o carnaval, contudo, são sobretudo os jovens que regressam para participar da festa.

\section{O CARNAVAL JÁ NASCEU CONOSCO, JÁ OS VELHOS FAZIAM ISSO}

O carnaval constitui um sistema simbólico associado à transição do Inverno para a Primavera, do velho para o novo, da morte para a vida, do frio para o calor, da parte masculina para a parte feminina do universo, reunindo diversos significados que assinalam esse ciclo na vida das comunidades rurais um ciclo de renovação cósmica e social, tempo de utopia e transgressão, no qual tudo o que é socialmente marginalizado busca libertação catártica, vencendo simbolicamente a hierarquia, a ordem, a opressão e o sagrado. Na Idade Média as festas carnavalescas convertiam-se simbolicamente na "segunda vida do povo", que ascendia, temporariamente, ao reino da utopia, da universalidade, da liberdade, da igualdade e da abundância (BAKHTIN, 2002). O carnaval constitui um ciclo na vida das comunidades, mais ou menos representativo conforme os significados que as pessoas lhe atribuem:

O significado histórico é mais importante do que o significado que eu lhe atribuo como participante. O significado desta quadra festiva é para mim gozo e prazer, mas o significado histórico já vem da Idade Média e mistura o profano com o religioso. Como o ano é dividido liturgicamente, o carnaval é o aliviar de uma certa carga religiosa. Antes as pessoas eram mais participativas na Igreja católica e então tinham estas fugas para libertar o seu espírito e sair um bocadinho da rotina (Norberto Carvalho, presidente da Junta de Freguesia). ${ }^{2}$

Nessa perspectiva, todas as formas e símbolos da linguagem carnavalesca estão impregnados do lirismo, da alternância, da renovação, e da consciência sobre a relatividade das verdades e autoridades do poder (BAKHTIN, 2002, p.10). Segundo Veiga de Oliveira (1984, p. 38), o carnaval provém das Saturnais romanas, que se caracterizavam como um período de completa liberdade licenciosa, durante o qual tudo era permitido. Esse ciclo temporal, em que o curso normal da vida é suspenso, dando lugar a rituais de inversão e subversão, contrariando a ordem social, pode ser designado por "liminar" (TURNER, 1990, p.117), com os seus "rituais de passagem" (VAN GENNEP, 1978, p. 31). Em 
Lazarim, o carnaval foi recordado pelos mais idosos como um tempo vivido no interior da comunidade, como prática de resistência aos poderes instituídos e como paródia burlesca:

O carnaval já nasceu conosco e já os velhos faziam isso, mas o carnaval era mais rigoroso nesse tempo, o pessoal não era tão educado. Qualquer briga de namorico ou da rega das águas, era pago nestes dias. Havia quase sempre zaragatas (...) Também acompanhei o farranjo, mas no entanto eu livrava-me das marés, que é quando via a coisa a ficar azeda, porque às vezes o carnaval durava mais de um ano pelos tribunais (José Rua, aposentado). ${ }^{3}$

O carnaval serviu para "ajuste de contas" entre vizinhos, mas também para afrontar os poderes instituídos. As práticas rituais de inversão nas sociedades católicas ocidentais assinalam um tempo de utopia. Esse tipo de pensamento utópico, disfarçado de forma alegórica, revela uma declaração explicitamente revolucionária, em que os dominados concebem a inversão e a negação de uma ordem social, radicalmente diferente daquela que vivem (scotT, 2003, p. 126). Durante o Estado Novo as práticas carnavalescas em Portugal estavam sujeitas à aprovação das autoridades locais, muitas vezes dominadas pela Igreja. Em Lazarim proibiram-se os mascarados (caretos) e a leitura dos testamentos do compadre e da comadre, por intervenção direta do pároco local junto ao bispo de Viseu.

O entrudo, com os testamentos, era para a Igreja de então algo prejudicial para a moral da sociedade. Então eles nesses dias em que esperavam que ia haver este tipo de rituais mandavam vir a GNR, eram as histórias que os meus pais contavam dos anos $30 \mathrm{e}$ 40 (Norberto Carvalho, presidente da Junta de Freguesia).

Na década de 1940 era comum o pároco local pedir um destacamento da Guarda Nacional Republicana - GNR para reprimir possíveis manifestações de desobediência. Num desses anos, os guardas da GNR estavam reunidos em casa do pároco, comendo e bebendo, quando foram surpreendidos pelo disparo de um tiro de caçadeira, que os pretendia amedrontar. $\mathrm{O}$ alvoroço na aldeia foi generalizado, e procederam-se a buscas e interrogatórios para encontrar o culpado. No decorrer das averiguações foram chamados ao Regedor todos os homens que tinham armas de caça, e a aldeia acorreu em peso. Quando o processo chegou ao juiz de Lamego estavam envolvidos todos os homens da aldeia, unidos em protesto coletivo, mas foram ilibados da sentença e prevenidos pelo juiz a não repetirem o sucedido. Na aldeia todos sabiam que o autor do disparo era o filho do Regedor, mas nunca o denunciaram. A sua 
ação representou uma vontade coletiva, e uma forma de resistência ao poder dominante. ${ }^{4}$

Havia muitas vinganças. Eu tinha uma tia que era professora primária, mas era muita má. E não havia entrudo em que ela não saísse para moer, inclusive no marido. Para dar pancada, mas pancada a sério (...) Eram as mulheres que se vestiam de careto. É um ritual de inversão não tenha dúvidas, é assim que eu me lembro da minha infância (Amândio Lourenço, presidente da Casa do Povo). ${ }^{5}$

Lembro-me do carnaval desde novinha, mas não era assim, saíam mais vezes mascarados com uns paus, e a canalha sempre atrás deles, a gente era nova e gostava imenso e agora também gosto muito. Só uma vez é que fiz um testamento, ainda não namorava o meu marido. Achava graça e também gostava de meter a minha achada contra eles. Eles eram mais atrevidos do que agora, não com falta de respeito às raparigas que havia muita, mais do que agora, mas nas zaragatas (Elvira Fernandes, aposentada). ${ }^{6}$

O carnaval aqui em Lazarim sempre foi meio maroto, até que agora nem é, é bonito e é um sossego. A evolução da vida é que faz isso. Antigamente as freguesias não se podiam ver umas às outras, agora os daqui casam com os de fora, os de fora casam com os daqui, e a evolução do tempo é que vai fazendo isto, e cada vez a coisa está mais normalizada, e assim é que é bem (Afonso de Almeida e Castro, artesão de máscaras). ${ }^{7}$

Os testamentos da comadre e do compadre tiveram consequências sociais graves, que se refletiram em processos judiciais e noivados desfeitos. A memória coletiva preserva esse tempo de conflitos, atribuindo à evolução dos tempos a normalização das relações entre vizinhos. Por outro lado, a institucionalização das práticas carnavalescas retirou o componente de transgressão e de secretismo que girava em torno dos caretos, e do grupos das comadres e dos compadres. A leitura dos testamentos realizava-se nos três lugares de Lazarim, permitindo a criação de um percurso que envolvia todo o espaço da comunidade numa unificação simbólica. Atualmente concentrase no Largo do Padrão, diante do edifício da Junta de Freguesia. Essa alteração obriga os habitantes a deslocar-se a um único lugar, mas permite aos forasteiros acompanhar todas as fases do ritual. As práticas carnavalescas transformaramse numa representação performativa para visitantes, e a animação dos caretos resume-se a um desfile de mascarados, posando para sessões fotográficas, sem desempenhar o papel socialmente desestabilizador pelo qual são recordados. 
Para o processo de reativação e reinvenção das práticas carnavalescas foi determinante a ação dos membros da Casa do Povo e da Junta de Freguesia, em colaboração com a escola primária e o Núcleo da Telescola, coordenado pelo professor Joaquim Simões: ${ }^{2}$

Nós, escola, temos feito intervenções junto da localidade começando pelo carnaval. Levamos para a escola toda essa vivência do carnaval, desde a confecção das máscaras, nas aulas de EVT, às fardetas e à própria gastronomia. Eles trazem as carnes, e as mães vêm ajudar a fazer o caldo de farinha, e partilhamos isso tudo como uma família alargada.

A Junta de Freguesia e a Casa do Povo, com o apoio da Câmara Municipal de Lamego, asseguraram os meios financeiros para a organização da festa; no sentido de a preservar, contudo, esse processo pode ser analisado pelo ponto de vista da institucionalização, como testemunha Amândio Lourenço:

Eu, ao criar a Casa do Povo em 1981, peguei no assunto. Deu-seIhe orientação, deu-se-lhe ritmo, organizou-se, está a perceber? Em vez de ser livre sem qualquer intervenção de ninguém a organizar, passou a ser a Casa do Povo a assumir as custas. Da sua originalidade não perdeu nada, deu-se-lhe foi mais um bocado de orientação, de organização para que os media tirem mais proveito desse trabalho. Porque o princípio que nos rege é particularmente o mesmo (...) O objetivo foi preservar uma das mais ricas tradições de Lazarim que foi e é, a tradição mais rica. O objetivo é cultural, mas hoje já tem um peso comercial tremendo.

A promoção e a divulgação do patrimônio cultural têm obviamente contrapartidas econômicas, sobretudo para os pequenos comerciantes locais e para os artesãos das máscaras de madeira, mas têm igualmente uma contrapartida simbólica que não pode ser ignorada, o prestígio dos agentes culturais. O prestígio é observável no nível da presença dos representantes do poder local e regional, de pesquisadores e museólogos, como roteiro cultural de elites urbanas, e pela presença de representantes da comunicação social em escala regional e nacional. Contudo, a reinvenção da tradição revela esquecimentos, que permanecem nas memórias de alguns membros da comunidade, como recordou Isabel Loureiro: ${ }^{9}$

Perdeu-se a semana das amigas e dos amigos porque as pessoas esqueceram-se um bocado e a vida também mudou. Nesses dias e nessas semanas havia comidas associadas e era uma forma de a mulher, que não podia aparecer nem podia dar a cara, e então castigava o homem em casa, para ele ter cuidado com aquilo que fa- 
zia depois. Era engraçado e eu já nem me lembro como era bem, os meus pais é que têm isso escrito lá em casa.

Alberto Correia (2003) elaborou um calendário do ciclo do carnaval em Lazarim, associando as relações de poder entre os grupos de gênero, com as comidas confeccionada à base de carne de porco. O calendário iniciava-se no quinto domingo anterior ao domingo gordo, assinalando a Semana dos Amigos. Durante essa semana a mulher exercia o poder sobre o homem, através da comida que confeccionava, "o homem era castigado com a apresentação de alimentos de pouca valia, como um caldo de farinha com moira". Na semana subsequente, a Semana das Amigas, "as mulheres como donas do lar não prescindem de iguarias, como a chouriça, um enchido nobre que desafia a magreza da moira". No domingo seguinte iniciava-se a Semana dos Compadres, com os homens ainda subalternizados e condicionados ao consumo da moira. Por oposição, na subsequente Semana das Comadres, as mulheres deliciam-se com salpicão (CORREIA, 2003, p. 18-19). Durante as semanas dos compadres e das comadres os grupos realizavam peditórios a fim de angariar fundos para a construção de suas mascotes, que hoje são encomendadas pela Casa do Povo a um artesão local. As relações de poder entre os grupos de gênero traduziam a submissão da mulher durante a vivência quotidiana na comunidade. A festa criava o espaço de exceção, e a utilização de práticas catárticas que permitiam ao grupo a criação de um mundo alternativo.

\section{TODOS OS ANOS SAÍAMOS MASCARADOS}

Os estudos etnográficos sobre festas de Inverno no norte de Portugal classificam o mascarado como um representante do diabo, da morte, do riso, do vício, gozando de impunidade em todos os níveis, em que "os mascarados da festa dos rapazes, tal como todas as personagens do nordeste transmontano, são veículo de um discurso mais ou menos simbólico e ritualizado ligado à transgressão, à licenciosidade e à liminaridade" (NETO JACOB, 1995, p. 386). A máscara é a expressão das transferências, das metamorfoses, das violações das fronteiras naturais e da ridicularização, baseada numa peculiar inter-relação da realidade e da imagem, característica das formas mais antigas dos ritos e espetáculos (BAKHTIN, 2002, p. 35). Como nos diz Lévi-Strauss (1981, p. 124), "uma máscara não existe em si (...) não é aquilo que representa mas aquilo que transforma, isto é: que escolhe não representar. Como um mito, uma máscara nega tanto quanto afirma; não é feita somente daquilo que diz ou julga dizer, mas daquilo que exclui". 
Figura 1: Afonso de Almeida e Castro trabalhando Foto da autora
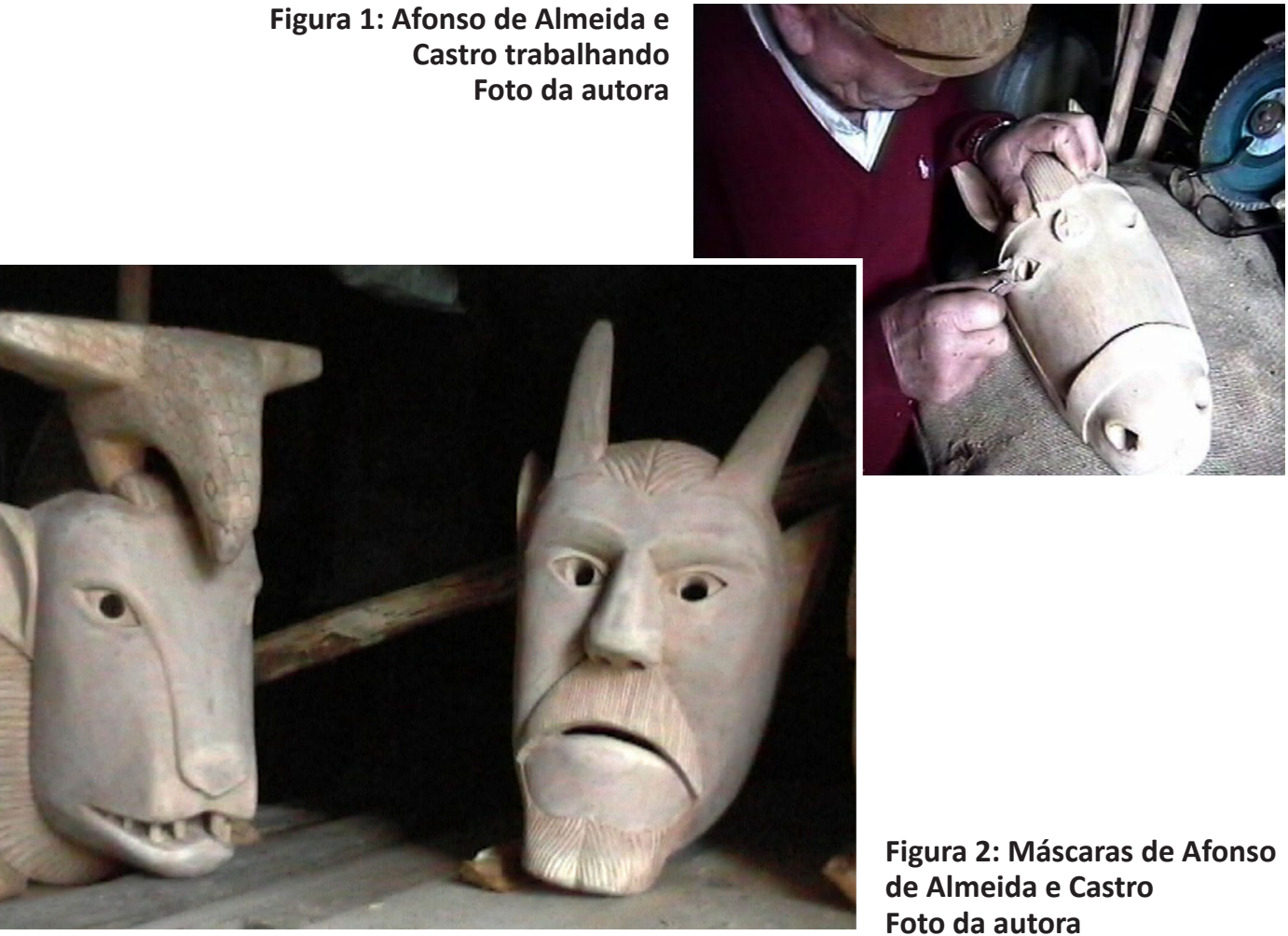

Figura 2: Máscaras de Afonso de Almeida e Castro Foto da autora

Em Lazarim, três gerações de artesãos, com diferentes expressões artísticas, transfiguram um tronco de amieiro, árvore que nasce nas margens do Rio Varosa, em figuras representativas da tradição local (figuras 1 e 2). Cada um desses homens registra simbolicamente em suas máscaras seu universo cultural e seu imaginário. Afonso de Almeida e Castro nasceu em Lazarim, em 1926, descendente de uma das famílias mais antigas da vila. Seu pai foi regedor durante vários anos, e com a família aprendeu a arte de trabalhar o campo:

Os meus pais viviam do campo e ajudava-os quando era pequeno. Naquele tempo não havia dinheiro para comprar máscaras de plástico, nem plástico havia, que eram de cartão. Mas já existia isto, sem ser eu, isto não vem de mim, já vem de tradição antiga. E como eu não tinha dinheiro e queria brincar ao carnaval resolvi fazer de madeira. Eu tinha os meus 16, 17 anos quando comecei a fazer as máscaras, mas era como calhava, era dois buracos e uma boca, pronto, e um nariz. Umas saíram mal, outras começaram a sair menos bem, e outras a sair bem. Quando regressei do Brasil, esses rapazes que já sabiam que eu as fazia pediram-me para fazer. Vendiaas a 25 tostões. 


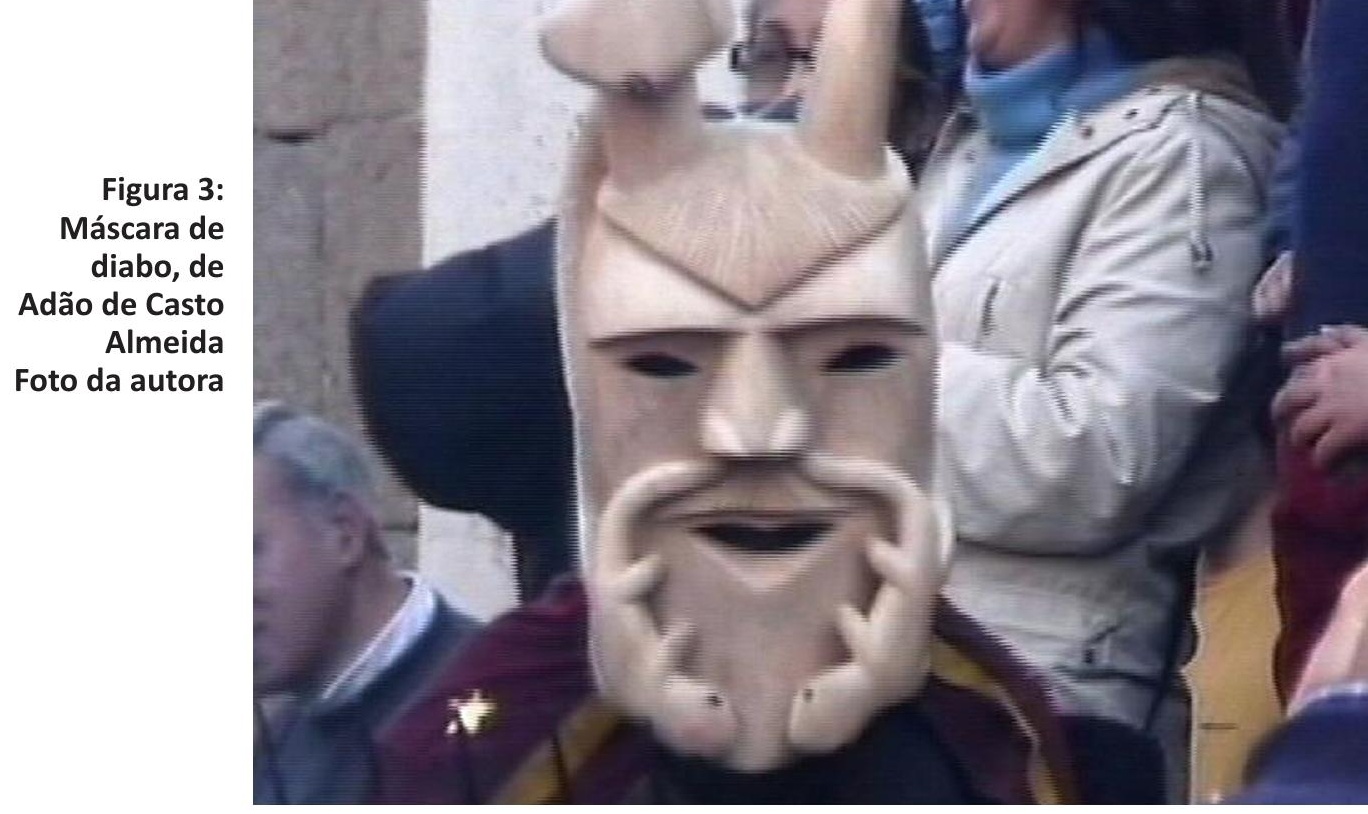

Afonso de Almeida e Castro é o mais antigo artesão de máscaras de madeira, mas faz questão de afirmar não ser o primeiro; outros houve antes dele, enunciados nas narrativas dos mais idosos. As máscaras de Alberto Costa, Miguel Matança e do tio Mansinho do Travasso serviram de modelo para se iniciar na arte, mas foi sem dúvida a experimentação o elemento fundamental de aperfeiçoamento que Ihe permitiu construir mais de 1.500. Sua máscara de diabo, pintada de vermelho, foi cartão de visita do carnaval de Lazarim durante a década de 1980, e sempre pintou as máscaras, até o dia em que a "reinvenção da tradição" Ihe impôs a cor natural da madeira, como modelo a reproduzir. As máscaras do diabo continuam a ser as mais solicitadas, mas também constrói figuras míticas de seu imaginário.

Segundo as narrativas dos mais idosos era comum pendurarem nas máscaras do diabo cobras do rio, sardões, sapos e sardaniscas, que se contorciam, conferindo ao mascarado um aspecto ainda mais assustador. Essas memórias tomam forma nas máscaras de Adão de Castro Almeida, um dos artesãos de máscaras mais conhecido de Lazarim (Figura 3).

Adão nasceu em Lazarim em 1962, é calceteiro de profissão na Câmara Municipal de Lamego, e constrói máscaras há aproximadamente 20 anos. Suas mãos, hábeis na colocação da pedra, potenciam outras técnicas que a experiência foi aperfeiçoando ao longo dos anos, dedicando seus tempos livres à construção das máscaras. Esse gosto, incorporado, remete às práticas carnavalescas de sua infância, tornando seu trabalho tão misteriosamente 


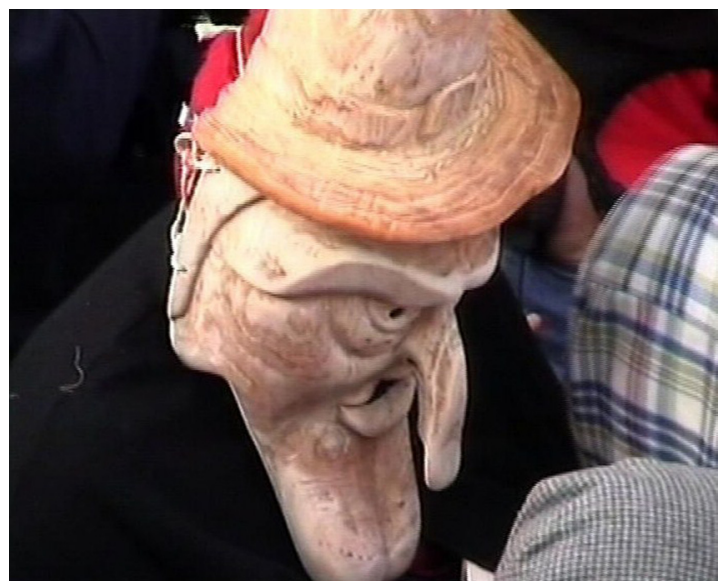

\section{Figura 4: Máscara da bruxa de Costinha \\ Foto da autora}

personalizado. A máscara do diabo, construída por Afonso de Almeida e Castro, despertou em Adão de Castro Almeida o gosto pelas máscaras, quando tinha 14 anos de idade:

Todos os anos saíamos mascarados ... então o Leonel aparece lá com um diabo pintado, era uma máscara das mais antigas (...) A partir daí comecei a fazer, gostei daquilo, por acaso foi, foi mesmo um gosto (Adão de Castro Almeida). ${ }^{10}$

José Antônio da Silva Costa, mais conhecido por Costinha, nasceu em 1974 em Vila Nova de Gaia e é carpinteiro. Com sete anos de idade veio para Lazarim, e aprendeu com o pai, carpinteiro de profissão, a arte de transformar a madeira. Mas foi na escola que apreendeu outras técnicas e o gosto pela construção de máscaras:

Comecei na Telescola a fazer máscaras de papel. Depois de madeira, uma coisa simplesinha, e daí para a frente fui-me incentivando, e o próprio presidente da Junta foi-nos incentivando para fazer, e venho fazendo máscaras há 17 anos (Costinha). ${ }^{11}$

A madeira utilizada é o amieiro, por ser mais fácil de trabalhar, segundo nos diz: o amieiro é uma árvore que absorve muita água, permitindo trabalhar a madeira enquanto está molhada. Mas, depois de seca, pode estalar. Os instrumentos são os que lhe são familiares na arte da carpintaria. Costinha é o único construtor que reúne na produção de seu trabalho os saberes aprendidos institucionalmente, através da escola e da família e o saber fazer, resultante da sua incessante experimentação. Suas máscaras representam figuras humanas ou bruxas do imaginário coletivo, mas recusa-se a construir máscaras de diabos. Costinha não incorporou, da mesma forma que os outros artesãos, o sistema simbólico do carnaval local. Seu gosto incide sobre caricaturas de figuras públicas, reproduzindo em seus trabalhos a influência dos meios de comunicação social. Mas o processo de institucionalização e o concurso de máscaras organizado pela Casa do Povo, obrigam-no à criação de figuras 

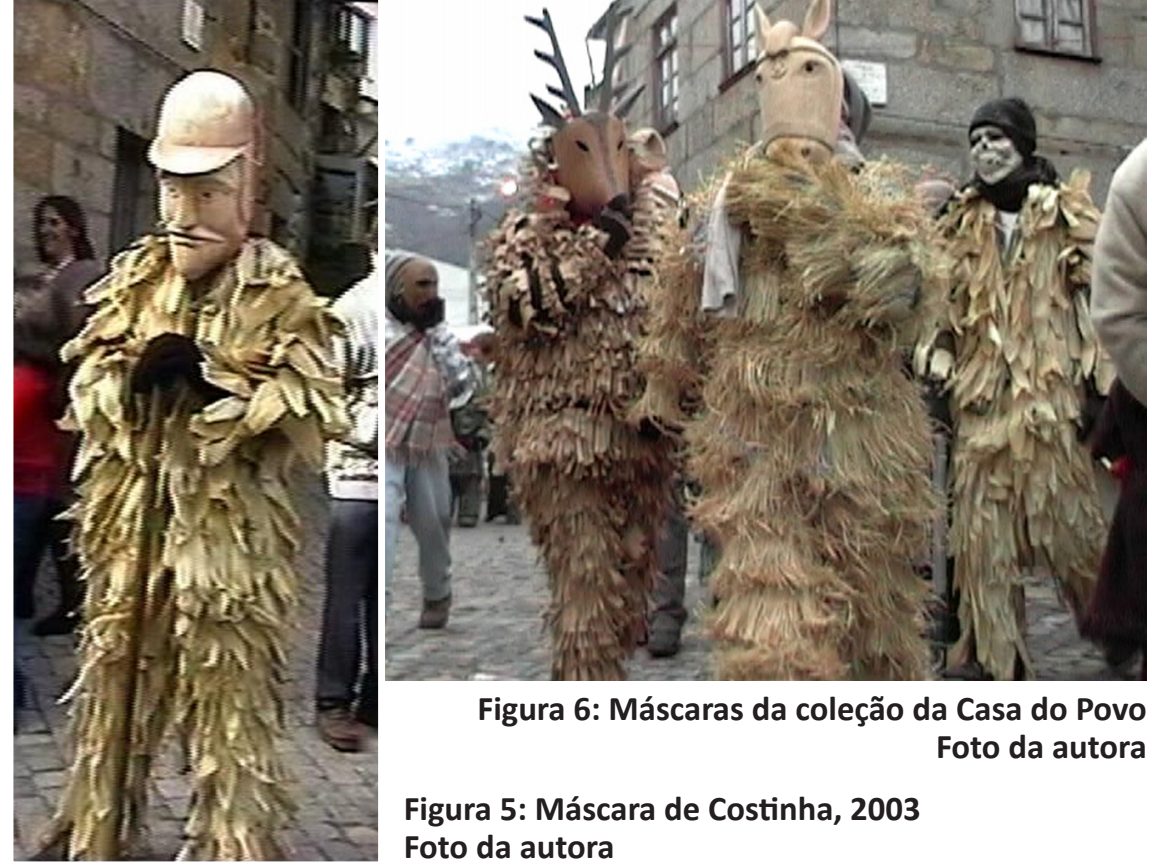

Figura 6: Máscaras da coleção da Casa do Povo

Foto da autora

\section{Figura 5: Máscara de Costinha, 2003} Foto da autora

representativas da "tradição". Como exemplo paradigmático do trabalho de Costinha, é interessante referir que utilizou uma caricatura de Vítor Baía, goleiro do Futebol Clube do Porto, como modelo para a execução de sua máscara de bruxa de 2003 (Figura 4).

Os caretos de Lazarim exibem através de suas máscaras representações de figuras históricas como bispos, reis e romanos, de figuras místicas como bruxas e diabos, de figuras grotescas, e ainda figuras de animais, como o burro, a corsa, o mocho e o porco. Os elementos que constituem as máscaras têm o valor de um signo, posto que reúnem em si um significante, no nível da expressão plástica, e um significado, no nível de seu conteúdo, como elementos constitutivos de uma linguagem apreendida no sistema simbólico da comunidade. Para os visitantes, a leitura será certamente diferente, resultante de seus sistemas de valores culturais. Como assinalava Umberto Eco, "cada um preencherá com os significados que lhe forem sugeridos pela própria situação antropológica, pelo seu modelo de cultura" (ECO, 1986, p.127). Nesse sentido, o sistema de significação das máscaras só pode ser interpretado, traduzido ou decodificado como discurso por referência a uma estrutura sociocultural, entendendo-se por estrutura o contexto local em que o discurso é produzido.

Os caretos completam a máscara com outros elementos de vestuário, como vestes confeccionadas em palha ou barba de milho entrançada, capas vermelhas ou negras com debruados. Na mão, transportam quase sempre um objeto de uso agrícola, como enxada ou forquilha, havendo alguns que usam um cajado de nogueira, que nos remetem ao sistema simbólico do mundo rural (figuras 5 e 6). 


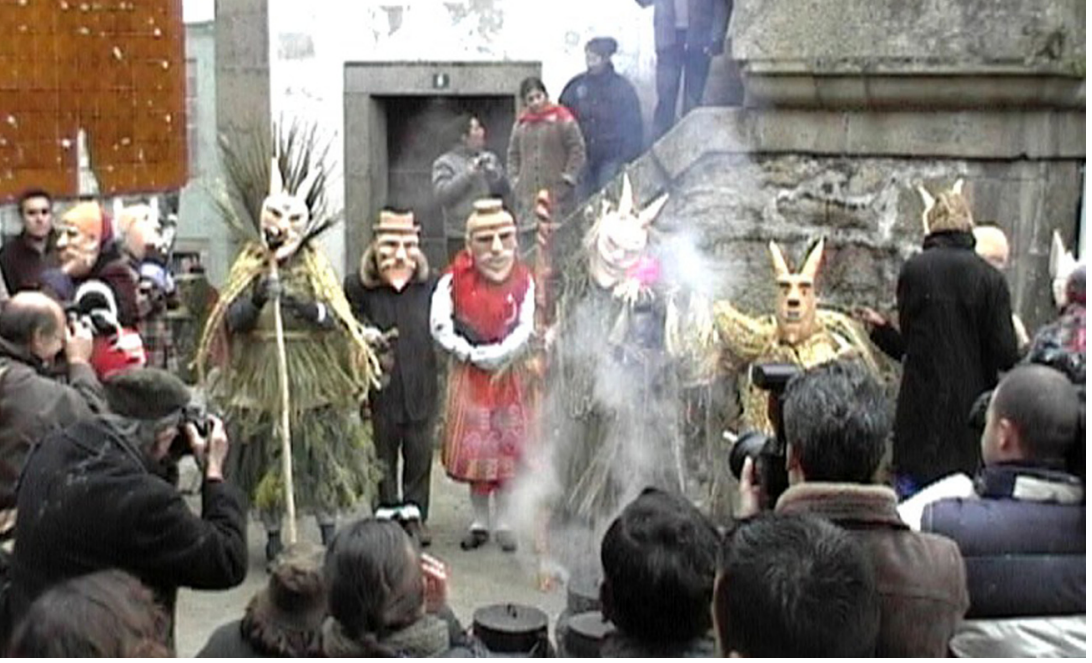

Figura 7: Largo da

Casa do Povo

Foto da autora

Os caretos de Lazarim, outrora elementos de desordem no seio da comunidade, transformaram-se em peças de artesanato local, para consumo dos mais abonados. Contudo, para as pessoas de Lazarim, as máscaras são motivo de orgulho e referência cultural simbólica não pelo que hoje representam, mas pelas memórias que suscitam. As máscaras, como sistema de signos, podem não ter leitura idêntica por parte de toda a audiência, mas, parafraseando Lévi-Strauss, "as máscaras também servem para pensar".

\section{O SIGNIFICADO DESSE RITUAL É MAIS UM GLADIAR ENTRE HOMENS E MULHERES}

O ritual é atividade orientada por normas, com caráter simbólico, que chama a atenção de seus participantes para objetos de pensamento e de sentimento, que eles consideram ter um significado especial (LUKES, apud CONNERTON, 1999, p. 22). O início do ritual é sinalizado pelo ribombar dos foguetes às três horas da tarde da terça-feira gorda. No Largo do Padrão começam a afluir os primeiros caretos, lançando farinha e jatos de água sobre os forasteiros e os locais. Os forasteiros respondem com disparo de câmaras fotográficas, tentando registrar tudo aquilo que foi anunciado como tradicional. No Largo da Casa do Povo, homens e mulheres preparam em grandes panelas de ferro "o banquete", a feijoada que no final do ritual será partilhada por visitantes e locais. Os homens carregam lenha, ateando o fogo, e as mulheres aprontam os ingredientes - feijão-branco, enchidos, entrecosto e orelha de porco. No centro da Vila, outro grupo de mulheres prepara o caldo de farinha, composto de farinha de milho, couves e enchidos de porco, que tem também a finalidade de ser consumido depois do ritual do testamento. Entretanto, soam as primeiras batidas dos bombos que ecoam no Largo do Padrão. O grupo de tocadores é constituído por quatro elementos que tocam um par de bombos e 
O grupo das comadres e dos compadres são representados por duas moças e por dois rapazes, solteiros. Um representante de cada grupo será escolhido para leitor do testamento, e o outro, transporta a mascote; o boneco simbolizando o compadre e a boneca simbolizando a comadre. O significado atribuído à representação dos gêneros, através da figura dos bonecos, é particularmente relevante, uma vez que as cores de suas roupas e adornos são de exuberância que contrasta com o vestuário comum dos membros da comunidade - o que reafirma não se tratar de representação simbólica das categorias presentes, mas da utopia, a imagem de um estado futuro (CONNERTON, 1999, p. 50).

O significado desse ritual é mais um gladiar entre homens e mulheres. Nesta altura própria do ano, de se enfrentarem. De o homem se pôr no nível da mulher, e a mulher no nível do homem, o rico no nível do pobre, e o pobre no nível do rico. Ali, naquele dia, todos mudam sua máscara. Todos se invertem, e acho que é esse o significado principal (Amândio Lourenço).

A ordem que assinala o início do ritual é dada pelos bombos, organizando-se novo cortejo até ao Largo do Padrão, onde serão lidos os testamentos da comadre e do compadre. Os caretos vão à frente, seguidos por representantes dos grupos e, por fim, tocadores e acompanhantes, população e forasteiros.

O testamento que fazemos às comadre é deixar-lhes uma peça do burro (...) Há partes que a gente gosta mais de dar, ou seja, as partes mais sexuais do burro (Paulo Loureiro).

E é nessa hora que vão ser descritos os defeitos, qualidades não (Márcia Castro Almeida). ${ }^{13}$

No Largo do Padrão foi montado um palco improvisado, em que os compadres e as comadres tomam seus lugares dando início à leitura dos testamentos, cujo texto tem três partes; a introdução, composta por quadras alusivas ao ciclo do carnaval e pela identificação da(o) testamenteira(o); as "deixadas" ou quadras dedicadas a todos os rapazes e moças solteiras; e o final, alusivo ao fim da comadre e do compadre, anunciando a morte e rebentamento pelo fogo.

Com a fome que trazeis / Passais a vida a ladrar / Comeis a burra inteirinha / Nem a rata vai escapar. / Para manter a tradição / E o carnaval não findar / Vamos repartir a burra / Para a boca vos calar.

O final de cada verso é sempre sinalizado com o rufar dos bombos. $\mathrm{O}$ texto é sarcástico, jocoso e vernáculo, recorrendo ao uso de alguns palavrões e 
abordando sobretudo os defeitos de caráter e de comportamento, tendo como acentuação a vertente sexual.

Tudo o que a gente diz é verdade, não inventamos nada. Mas eles não têm dificuldade nenhuma em chamar nomes e dizer tu és isto e tu és aquilo (Isabel Loureiro).

Nós às vezes também exageramos um bocadinho, tudo o que dizemos não é verdade, às vezes temos de dizer assim umas coisas mais picantes para quem vem de fora. Eles só acham graça quando dizemos coisas picantes mesmo (Paulo Loureiro).

O texto dos compadres acentua igualmente os defeitos de caráter e os comportamentos das moças, mas tem mais incidência nos aspetos da vida sexual, utilizando uma linguagem mais jocosa, recorrendo ao uso de palavrões e dando-lhe uma forma mais grotesca do que o das comadres, mas essa construção verbal é consciente.

Como já estavam há espera / Está cá o fanfarrão / Para dar carninha a todas / E manter a tradição. / A todas vamos dar carne / Pois é isso que elas querem / Não importa de quem seja / Consolar-se elas preferem.

Os testamentos carnavalescos no uso de linguagem jocosa, nas injúrias e nos palavrões, que constituem as "deixadas", remetem sempre a um paralelismo entre as características do beneficiário e o objeto de partilha. De acordo com nossos informantes o significado desse ritual é "mais um gladiar entre homens e mulheres", elegendo como bem de partilha, o burro e a burra, num paralelismo masculino/feminino que acentua as relações sociais e simbólicas entre pares de opostos. A figura do animal parece adquirir duplo significado: o de símbolo bíblico da humilhação e da docilidade, e o do corpo grotesco cômico decepado, quando valorizadas as partes sexuais, objeto de partilha. "É o Paulo já se vê, / Vai repartir a burrinha, / Fica com a melhor parte, / Essa será a ratinha."

A audiência, composta por pessoas de vários grupos etários, reage pelo riso ao desfilar dos versos, contrastando com a postura séria dos leitores. Os grupos de rapazes e moças vão partilhando entre si cumplicidades através da troca de olhares. Também é possível observar que o testamento dos compadres provoca quase sempre mais gargalhadas na assistência do que o das comadres. Outro aspecto interessante nos textos é a referência a "manter a tradição", presente em ambos os testamentos, reforçando por fixação e repetição a ideia de continuidade por incorporação, em que os ritmos da poesia oral são os mecanismos privilegiados de recordação (CONNERTON, 1999, p. 88). Após a leitura dos textos é organizado um cortejo, durante o qual solenidade e 
contenção são assumidas pelos participantes que se dirigem para o sítio da Cruzinha, em Valverde, onde os bonecos serão consumidos pelo fogo. Os caretos tomam a dianteira, seguidos por compadres e comadres. Os tocadores impõem batida lenta e compassada, como num cortejo fúnebre, seguidos pela população local e pelos forasteiros (figuras 9 e 10).

No lugar da Cruzinha, em Valverde, os bonecos armadilhados por efeitos pirotécnicos, vão rodopiando, produzindo ruído e chamas acompanhadas de sucessivas explosões e batidas dos tocadores, até ao estouro final, provocando na assistência, sobretudo nas crianças, enormes alegria e algazarra que perduram na memória.

Recorda-me de gostar de ver o compadre e a comadre a andarem a rabiar num arame ou num pau. Logo a seguir ao Natal começávamos a brincar o carnaval. Marcou muito a nossa infância em Lazarim (Norberto Carvalho).

Quando rebentam, para mim representa o encerramento do que de bom se tinha passado para trás, é a morte do compadre e da comadre, quer dizer que a partir desse momento a vida volta à normalidade, o carnaval acaba ali (Paulo Loureiro).

Em Lazarim a imolação dos bonecos assinala o término do ritual da festa carnavalesca, seguindo-se-Ihe o "banquete", espaço de confraternização entre os membros da comunidade e os forasteiros, através da comensalidade. $\mathrm{O}$ rito de passagem está concluído, mas o processo de reinvenção da tradição inseriu novos elementos à festa, o concurso de máscaras. O concurso é organizado pela Casa do Povo para premiar e incentivar os artesãos de máscaras de madeira, e manter a continuidade e a tradição. Esse é um dos momentos da festa em que a audiência é essencialmente composta pelos membros da comunidade, artesãos e seus familiares. O júri do concurso é constituído por pessoas convidadas, externas à comunidade. Os prêmios atribuídos contemplam a melhor máscara em seu conjunto (vestes e máscara), a melhor máscara de madeira, a primeira máscara, e prêmios de participação, como incentivo e reconhecimento pelo trabalho desenvolvido. Durante o concurso a maior parte dos visitantes dispersa-se pelos lugares em que são oferecidos os "banquetes".

No Largo da Vila saboreia-se o caldo de farinha, e no Largo da Casa do Povo, a feijoada. A história a que remete a origem do banquete comunitário celebra a abundância do grupo social de tal forma, que seus membros se permitem convidar vizinhos e forasteiros para seu banquete. Segundo Bakhtin (1969), o triunfo do banquete é universal, representando o triunfo da vida sobre a morte, sendo nesse aspecto, o equivalente da concepção e do nascimento, 
A terça-feira de carnaval queríamos conservar, porque é uma identidade própria é alguma coisa que faz parte da nossa identidade e que nos dá algum valor. Somos reconhecidos também por isso. Estamos tirando alguma riqueza social e intelectual desse tipo de eventos e vamos aproveitá-los dando conhecimento do que se passa aqui em Lazarim ao país e ao mundo, a fim de deixar uma referência para as pessoas que vierem mais tarde.

O discurso institucional justifica as razões que levaram à reinvenção da tradição como patrimônio cultural e sua importância para a projeção da comunidade. Apesar de haver cada vez menos jovens que garantam a continuidade das práticas carnavalescas em Lazarim, tudo indica que o interesse dos poucos que restam é cada vez maior. Esse fenômeno foi igualmente identificado por Paula Godinho (1995) com relação aos caretos do nordeste transmontano, que após interregno de alguns anos, e querendo retomar as práticas carnavalescas, recorreram às memórias dos mais velhos, para reconstituir ou "reinventar a tradição". Além disso, tal como os intervenientes na construção da Festa dos Rapazes, também os jovens de Lazarim "se orgulham de ter presentes na sua festa investigadores, antropólogos portugueses e estrangeiros, museólogos e representantes da comunicação social" (GODINHO, 1995, p. 88). A divulgação da festa, sobretudo nos meios de comunicação social, serve para reforçar a identidade coletiva, projetando a comunidade local no mundo global.

\section{REFERÊNCIAS BIBLIOGRÁFICAS}

BAKHTIN, Mikhail. A cultura popular na Idade Média e no Renascimento. São Paulo: Hucitec/Annablume Editora, 2002.

BOURDIEU, Pierre. O poder simbólico. Algés: Difel. 2001.

CONNERTON, Paul. Como as sociedades recordam. Oeiras: Celta Editora. 1999.

COSTA, Gonçalves M. História do bispado e cidade de Lamego, v. I. Lamego. 1977.

CORREIA, Alberto. Máscaras de carnaval em Lazarim. Lamego: Edição da Câmara Municipal de Lamego. 2003.

ECO, Umberto. Viagem na irrealidade quotidiana. Lisboa: Difel, 1986.

GEERTZ, Clifford. A interpretação das culturas. Rio de Janeiro: Zahar Editores. 1978.

GODINHO, Paula. "Ser rapaz e ir à festa", Actas do Congresso A Festa Popular em Trás-os-Montes. Bragança, 1995, p. 81-92.

HALBWACH, Maurice. A memória coletiva. São Paulo: Centauro Editora. 2004.

HOBSBAWM E.; RANGER T. The Invention of the Tradition. Cambridge: Cambridge University Press. 1983. 
LÉVI-STRAUSS, Claude. A via das máscaras. Lisboa: Editorial Presença. 1981.

NETO JACOB, João Manuel. "Festas com máscaras: algumas leituras", in Actas do Congresso, A Festa Popular em Trás-os-Montes. Bragança, 1995. p.375-388.

OLIVEIRA, Ernesto Veiga de. Festividades cíclicas em Portugal. Lisboa: Publicações D. Quixote, 1984.

PINELO TIZA, António. "O Mascarado, suas funções nas festas do Inverno", in Actas do Congresso A Festa Popular em Trás-os-Montes. Bragança, 1995, p. 189-196.

SCOTT, James C. Los dominados y el arte de la resistencia. México: Editorial Txalaparta. 2003.

TURNER, Victor. "Are There Universal Performances in Mito, Ritual and Drama?". In SCHECHNER, Richard; APPEL, Willa (eds.). By Means of Performance, Intercultural studies of theatre and Ritual. Cambridge: Cambridge University. 1990.

VAN GENNEP, Arnold. Os ritos de passagem. Petrópolis: Vozes, 1978.

\section{NOTAS}

1 Agostinho Ramalho nasceu em Bigornes em 1964. Os pais eram naturais de Lazarim. Há cinco anos é pároco de Lalim e de Lazarim, onde reside. Excerto da entrevista realizada em Lazarim, em 3 de março de 2003.

2 Norberto Carvalho nasceu em Lazarim em 1961, filho de lavradores e comerciantes. É comerciante e o atual presidente da Junta de Freguesia de Lazarim. Pertenceu ao grupo dos Compadres. Excerto da entrevista realizada em Lazarim, em 3 de março de 2003.

3 José Rua nasceu em Lazarim em 1920 e frequentou o ensino primário. O pai foi juiz de paz em Lazarim. Dedicou-se à agricultura e aos 24 anos foi trabalhar em Lisboa, na empresa Roomar, mas regressou a Lazarim para desempenhar as funções de encarregado geral de obras na Câmara Municipal de Lamego, por onde se aposentou. Ainda pertence à Tuna de Lamego. Excerto da entrevista realizada em Lazarim, em 2 de março de 2003.

4 Depoimento de Afonso Almeida e Castro. Notas de campo de março de 2004.

5 Amândio Lourenço nasceu em Lazarim em 1953, filho de lavradores. Tem o curso geral de administração e comércio e é funcionário público na Segurança Social de Lamego. Foi presidente da Junta de Freguesia de Lazarim entre 1983 e 2002. É presidente da Casa do Povo de Lazarim. Excerto da entrevista realizada em sua casa, em Lazarim, em 2 de março de 2003.

6 Elvira Fernandes nasceu em Lazarim em 1923, filha de lavradores. Em 1944 casou com José Rua e teve nove filhos, mas só seis chegaram à idade adulta. Trabalhou no grupo familiar e é doméstica. Excerto da entrevista realizada em Lazarim, em 2 de narço de 2003.

7 Afonso Almeida e Castro nasceu em Lazarim em 1921, filho de lavradores. O pai foi regedor em Lazarim. Em 1944 emigrou para o Brasil, trabalhou na pesca, e viveu no Caju, no Rio de Janeiro, onde também vivem atualmente seus filhos e netos. Regressou a Lazarim em 1970 e dedicou-se à construção de máscaras. É o mais antigo artesão de máscaras de madeira. Excerto da entrevista realizada em Lazarim, em 3 de março de 2003. 
8 Joaquim Simões foi professor de educação visual e tecnológica (EVT) na Telescola de Lazarim durante 23 anos. Vive em Lamego e é subdiretor da região norte da Telescola. Foi responsável pela recuperação das práticas carnavalescas nas escolas de Lazarim. Excerto da entrevista realizada em Lazarim, em 4 de março de 2003.

9 Isabel Loureiro nasceu em Lazarim em 1978, mas migrou com os pais para Lisboa, onde vive atualmente. É escriturária de profissão. Faz parte do grupo das comadres e todos os anos se desloca a Lazarim para participar da feitura do testamento. Excerto da entrevista realizada em Lazarim, no dia 4 de março de 2003.

10 Excerto da entrevista realizada em Lazarim, em 3 de março de 2003.

11 Excerto da entrevista realizada em Lazarim, em 3 de março de 2003.

12 Paulo Loureiro nasceu em Lazarim em 1977. É filho de comerciantes locais e empresário no ramo de lavandarias em Lamego. Faz parte do grupo dos compadres desde os 15 anos de idade. Excerto da entrevista realizada em Lazarim, em 3 de março de 2003.

13 Márcia Castro Almeida nasceu em Lazarim em 1981 e é empregada de comércio em Lamego. Faz parte do grupo das comadres. Excerto da entrevista realizada em Lazarim, em 3 de março, de 2003.

Dulce Simões é antropóloga ligada à Faculdade de Ciências Sociais e Humanas da Universidade Nova de Lisboa, PHD em Antropologia (FCSH-UNL), membro da equipe de pesquisa do Inet-MD/FCSH-UNL, colaboradora do IELT/FCSH-UNL, do Cria/FCSH-UNL e do Grupo de Estúdios Sociales Aplicados de la Universidad de Extremadura. 